\title{
This New Place
}

Guiselle Phillips

$\mathrm{H}$ e woke up and as he did so he found himself in the strangest of places; even though he knew that this was an odd place, he could not remember where he had been before. The light hurt his eyes and the noises suppressed any kind of thought. He felt that he was becoming asphyxiated; the pain was more than he could withstand. "What is happening to me?" he thought, and when he was just about to give up she came to save him. And boy did he love her for it! He said so with the renewed twinkle in his eyes. She remained with him and taught him all kinds of things from this new place. She helped him learn how to move in the new textures and how to act around the variety of new objects. He was used to different sensations; before, he never felt cold or lonely. The new land was arid and aggressive; he felt like the whole world was out to get him. Everything in this new world was larger than him, making him feel like he was going to be crushed all the time. But he never complained, not even once; his spirit was too great to give up.

He then met the "humans" as she called them; they seemed to dislike him and he did not understand why. He thought that they looked weird with their bare skins and their absurd height, but then again, everything was massively large. One awful day he went to sleep and woke up in a completely different world, AGAIN. This time he was not in any pain but she was nowhere to be found. The textures were different as well; there, he found other creatures, gentler creatures. And even though he made friends, he missed her so much that his heart could not bear it. He decided that he would go back and search for her for as long as he had to, but there was something that he did not know. The first humans that he had met were sweet and gentle in comparison to the new humans that he encountered in this part of his journey. But I am getting ahead of the story.

He started walking across what the other creatures called grass and he liked it; he liked the smell, the color, the sensation on his feet, and even its taste. He also saw flowers and trees; the trees were a paradigm shift since they were even bigger than the other things that he had known and they made him wonder if he could ever find a place in which he could fit. He started feeling hungry; many hours had passed since he started traveling. Of course he did not know that it was called hunger and least of all how to fixit; shehad always provided him with food. How he missed her.

Merely by instinct, he followed a smell; it might have been the hunger but this smell was intoxicating, powerful, 
and delicious. He followed it until the border of the grassland and into something that he later learned to be concrete. The ground was sizzling hot and so dry that he could feel the moisture of his feet being transferred, but this smell kept him going. He finally found the source of this mysterious and enchanting smell when he encountered a problem; some kind of invisible barrier stood between him and the source of the deliciousness. He tried kicking, licking, and even screaming, but it did not work. Suddenly, he felt a blow on his left side that propelled him through the air; he screamed. "What had happened? Who did this to me?" he thought. There was a lot of yelling, he was disoriented, and afraid, not to mention the pain. He looked in the direction that he came from and saw a human, one that he had never met, armed with a stick and making gestures at him. He ran; he ran as fast as he could to get away from the scary monster until his legs could not run any longer. He continued to be hungry, he continued to be mistreated but never understanding why; maybe it was because he was different or maybe because they were afraid of him. The human race showed him no kindness but he never complained; he wanted to see her again and that was his fuel and his hope.

At first he could see something in the face of some humans, especially the small ones, that looked at him with tenderness; however, over time he found this kind of reaction less and less. He could tell that it was the way he looked what had changed; most of his hair had fallen and his bones were protruding from his frame. Now, he was hungry all the time; he had no idea of what time it was and even if he had, he could not have known how long it had been since he felt her warmth against his body. But he never focused on the bad, he was still hopeful in his quest.

For the first time since he had been in this strange blue marble he wondered why he was here, what the purpose was of all this suffering, and what he could do to make it stop. There was no more hope; he felt so alone, so ill, so weak... there was nothing else that could make him want to keep fighting. But that night he knew kindness in the form of a hot soup that a stranger gave him in the streets; this man spent hours with him talking about everything and nothing at the same time. Unfortunately, this new friend eventually had to leave and he was left alone in that cold and ruthless street, but at least he had a warm belly and a sparkle in his soul for the mercy that he had been shown.

The next day he pulled himself together again and charged towards the unknown; he decided that he was going to follow around the people that still had that tenderness in their eyes when they looked at him. And so he did. He followed a multitude of people back and forth; some of them helped him and some of them mistreated him. He was following one of those people when he saw that there was a human that looked at him with that special look, but this one was different; this one also had pity in those human eyes. Although his skin was decaying and he looked sickly, that human picked him up. He saw that she was crying and he licked her face in return; she said something that he understood not by the words but by her embrace "I am sorry for what you have been through puppy but I promise that you will never suffer again for this new place is now your home." 